Swarthmore College

Works

Fall 2018

\title{
Introduction To German Studies: The Romantics Then And Now (GMST 20) Syllabus
}

Madalina Meirosu

Swarthmore College, mmeiros1@swarthmore.edu

Follow this and additional works at: https://works.swarthmore.edu/dev-dhgrants

Part of the German Language and Literature Commons

\section{Recommended Citation}

Madalina Meirosu. (2018). "Introduction To German Studies: The Romantics Then And Now (GMST 20) Syllabus". Introduction To German Studies: The Romantics Then And Now. DOI: 10.24968/

2476-2458.dhgrants.30

https://works.swarthmore.edu/dev-dhgrants/30

\section{(c) (7)}

This work is licensed under a Creative Commons Attribution 4.0 License.

This work is brought to you for free by Swarthmore College Libraries' Works. It has been accepted for inclusion in Digital Humanities Curricular Development by an authorized administrator of Works. For more information, please contactmyworks@swarthmore.edu. 
Introduction to German Studies (GMST 20, Fall 2018)

The German Romantics: Past and Present

Instructor: Dr. Madalina Meirosu

Class location: Beardsley 305

Class hours: Tu/Th 11:20-12:35

Email: mmeiros1@swarthmore.edu

Office hours: TBA, and by appointment

Office location: Parrish 209

Office phone: $\mathrm{x} 6491$

\section{Course Description}

(NB: This course is taught in German and all of the assignments are in German. The detailed schedule in Moodle is also in German.)

This course serves as an introduction to the interdisciplinary field of German Studies. German culture has played a seminal role in the history and culture of modern Europe, influencing and shaping the European spirit in all manner of ways. However, rather than survey the rich history of contributions of German-speaking people to European and world culture, this course will focus on the relatively small period of German Romanticism (during the late $18^{\text {th }}$ and early $19^{\text {th }}$ century). As we proceed we will ask the following questions: what is German culture? How has it been defined? What is German Romanticism? What themes permeate the German Romantic tradition? How are they like or unlike themes in other similar literary traditions? Who are some significant figures in literature, music, philosophy, visual arts, architecture, and how have they influenced subsequent generations of artists and intellectuals? In addition to answering these basic questions, we will use the Romantics as a lens to learn about German culture on a larger scale. The Romantics' deep connection with earlier cultural époques, such as the Middle Ages, and their reaction against Classicism, Rationalism and the Enlightenment will give students a chance to learn about various movements of thought in German culture. We can then trace the echoes of the Romantics through the centuries to the present day and ask if there are contemporary cultural movements with sensibilities similar to those of the Romantics. Authors we will look at will include Wackenroder, Schelling, Schleiermacher, Schlegel, Tieck, Novalis, ETA Hoffmann, von Arnim, Hölderlin, Kleist, Goethe, Beethoven, Wagner, Schubert, Runge, Casper David Friedrich, Schinkel, Grimm.

Students will learn the vocabulary necessary for critical discussions of literature, visual arts, and cultural theory. Throughout the semester, short assignments will allow students to hone their writing skills. Additionally, class discussion, as well as short class presentations, will support the students' efforts to learn and correctly use the necessary vocabulary. During the semester, students will work on a digital project that consists of creating a timeline of the various cultural artifacts discussed in the classroom. This team-based project will introduce students to working with free online digital databases offered by German libraries and private online resources that contain information relevant to the study of German Romanticism. It will also afford students an opportunity to research and so more fully appreciate the historical circumstances and cultural backgrounds that have influenced the creation of the texts we will discuss in class. Students will also write an essay that will demonstrate their critical skills and use of vocabulary. 


\section{Readings and other materials}

\section{Textbooks}

Recommended textbook for grammar review:

Deutsche Wiederholungsgrammatik: A Morpho-Syntactic Review of German, by Frank E. Donahue (9780300124682).

\section{Fall 2018 accommodations statement}

If you believe you need accommodations for a disability or a chronic medical condition, please contact Student Disability Services (Parrish 113W, 123W) via

email at studentdisabilityservices@swarthmore.edu to arrange an appointment to discuss your needs. As appropriate, the office will issue students with documented disabilities or medical conditions a formal Accommodations Letter. Since accommodations require early planning and are not retroactive, please contact Student Disability Services as soon as possible. For details about the accommodations process, visit the Student Disability Services website. You are also welcome to contact me (Madalina Meirosu, mmeiros1@swarthmore.edu) privately to discuss your academic needs. However, all disability-related accommodations must be arranged, in advance, through Student Disability Services.

\section{Communication etiquette}

I will send emails from Moodle and post announcements in Moodle should anything occur that requires your attention. Please consider my office hours as a welcoming space in which to explore ideas, ask for help, or simply talk about German Romanticism and German culture. I will answer your emails within 24 hours, including during the weekend.

I expect students to let me know if there may be issues affecting their performance or attendance. You should email me in advance if you will miss a class. A short and discreet email stating that a medical/family emergency will prevent you from attending class is sufficient; there is no need to go into detail (unless you feel it would help you to share more).

\section{GRADING}

Four Tests $\quad 20 \%$

Homework (writing assignments, short essay, digital timeline class project) $\quad 30 \%$

In-class participation, 4 oral presentations $\quad 25 \%$

$\begin{array}{ll}\text { Final Essay } & 25 \%\end{array}$

Letter grades are formulated based on the following scale:

A+ 100-97; A 96-93; A- 92-90

$\mathrm{B}+89-87$; B 86-83; B- 82-80

$\mathrm{C}+79-77 ; \mathrm{C} 76-73 ; \mathrm{C}-72-70$

D+ 69-67; D 66-63; D- 62-60 
Please note that each unexcused absence will reduce your grade by one letter point (for example, A will become A-). You have to write to me in advance if you will miss a class and provide a valid reason for missing the class.

Assessment of participation occurs every class meeting and is based on the following criteria:

\begin{tabular}{|l|l|}
\hline Grade & Criteria \\
\hline A & $\begin{array}{l}\text { always well prepared; attentive and volunteers regularly; always uses } \\
\text { German with classmates and instructor; makes the most of each activity } \\
\text { or exercise; actively engages in discussions with original and thoughtful } \\
\text { contributions; responds to and engages classmates in a respectful } \\
\text { manner; remains critical and open-minded toward target and native } \\
\text { culture }\end{array}$ \\
\hline B & $\begin{array}{l}\text { usually well prepared; attentive and volunteers occasionally; uses } \\
\text { German with classmates and instructor; makes the most of each activity } \\
\text { or exercise; completes activities and exercises with some imagination and } \\
\text { resourcefulness; makes some effort to engage fellow students; shows } \\
\text { some development of cultural sensitivity }\end{array}$ \\
\hline C & $\begin{array}{l}\text { adequately prepared and attentive; rarely volunteers to answer general } \\
\text { questions; responds and completes exercises with minimal imagination; } \\
\text { does not engage classmates beyond the minimum requirements for an } \\
\text { assignment }\end{array}$ \\
\hline D & $\begin{array}{l}\text { usually unprepared; makes little effort to participate or complete } \\
\text { exercises; the German used is unintelligible }\end{array}$ \\
\hline F & makes no contribution to class whatsoever \\
\hline
\end{tabular}

\section{Einführung}

\section{Week 1}

\section{Sept. 4}

What is "German Studies;" why is "German Romanticism" a worthy subject of study in the $21^{\text {st }}$ century?

Novalis „Die Welt muß romantisiert werden“

Joseph von Eichendorff „Die blaue Blume“

Sept. 6

Periodisation(s)

Wackenroder „Von zwei wunderbaren Sprachen und deren geheimnisvoller Kraft“

\section{Week 2}

Sept. 11

Romantic ideas, romantic ideals

Film: „Die Geliebten Schwestern“

Wie schreibt man eine Inhaltsangabe

Sept. 13

Romantic ideas, Romantic ideals - in painting 
Kurzfilme: „1000 Meisterwerke. Caspar David Friedrich: Das Eismeer;““,100o Meisterwerke. Johann Christian Clausen Dahl: Blick auf Dresden bei Vollmondschein“"

\section{Lyrik}

Week 3

Sept. 18

Novalis „Wenn nicht mehr Zahlen und Figuren“

Eichendorff „Mondnacht;“" „Waldgespräch“

\section{Sept. 20}

Dorothea Schlegel „Draußen so heller Sonnenschein”

Friedrich Schlegel „Am Rheine“

Wilhelm Müller „Wanderlieder eines rheinischen Handwerksburschen Brüderschaft“

Wie schreibt man eine Gedichtinterpretation

\section{Week 4}

Sept. 25

Karoline von Günderode „Liebe”

Sophie Mereau-Brentano „In Tränen geh ich nun allein”

Bettine von Arnim „Wer sich der Einsamkeit ergibt“

\section{Sept. 27}

Achim von Arnim „An Bettine“

Anette von Droste-Hülshoff „Die Golems“

Adalbert von Chamisso „Der Invalid im Irrenhaus“

Week 5

Oct. 2

Clemens Brentano „Zu Bacharach am Rheine“

Heinrich Heine „Ich weiß nicht, was soll es bedeuten;“ „Im Rhein, im heiligen Ströme“

Oct. 4

Hölderlin „Der Rhein“

Ernst Moritz Arndt „Des Teuschen Vaterland“

Schreiben: Essay 1

\section{Prosa}

\section{Week 6}

Oct. 9

Film: „Das Fräulein von Scuderi“ (nach der Novelle von E.T.A Hoffmann)

\section{Oct. 11}

Film: Michael Kohlhaas (frei nach der Novelle von Heinrich von Kleist)

Wie schreibt man eine Filminterpretation?

Timeline Project presentations 
Week 7: Märchen

Oct. 23

2 Grimm Märchen

Wie analysiert man ein Märchen?

Oct. 25

De La Motte-Foque „Undine“

Week 8: Märchen

Oct. 30

De La Motte-Foque „Undine“

Nov. 1

De La Motte-Foque „Undine“

Wie schreibt man eine Charakterisierung?

Week 9: Kurzgeschichten

Nov. 6

E.T.A Hoffmann „Der Sandmann“

Nov. 8

E.T.A Hoffmann „Der Sandmann“

Schreiben: Vorschlag für Essay 2

Week 10

Nov. 13

E.T.A Hoffmann „Der Sandmann“

Wie analysiert man eine Kurzgeschichte?

Nov. 15

Achim von Arnim „Isabella”

Week 11

Nov. 20

Von Eichendorff „Marmorbild”

(Nov 21, Wednesday, Thanksgiving break after last class)

Week 12: Roman

Nov. 27

Novalis „Heinrich von Ofterdingen” (Fragment)

Nov. 29

Novalis „Heinrich von Ofterdingen” (Fragment)

Week 13

\section{Drama}

Dec. 4

Tieck „Der gestiefelte Kater” (Fragment)

Essay 2 als Referat vorstellen 
Wie analysiert man ein Drama?

Dec. 6

De la Motte-Foque „Sigurd der Schlangentöter” (Fragment)

Essay 2 als Referat vorstellen

Week 14

December 11 (Thursday schedule)

Tieck „Der gestiefelte Kater”

Timeline Project presentations

Letzte Fassung von Essay 2 am 16. Dezember vor Mitternacht per Email fällig 